\title{
Development and characterization of orally-disintegrating films for propolis delivery
}

\author{
Desenvolvimento e caracterização de filmes de desintegração para liberação oral de própolis \\ Josiane Gonçalves BORGES ${ }^{1}$, Marina TAGLIAMENTO ${ }^{1}$, Aline Guerra SILVA ${ }^{1}$, \\ Paulo José do Amaral SOBRAL ${ }^{1}$, Rosemary Aparecida de CARVALHO ${ }^{1 *}$
}

\begin{abstract}
This study aimed at evaluating the effect of different concentrations of hydrolyzed collagen (HC) on the properties of an orally disintegrating film containing propolis ethanol extract (PEE) as an active component. The films were evaluated in terms of total phenols, mechanical properties, solubility, contact angle, disintegration time, and microstructure. The films were prepared by casting with $2 \mathrm{~g}$ of protein mass (gelatin and $\mathrm{HC}$ ), $30 \mathrm{~g}$ of sorbitol/100 $\mathrm{g}$ of protein mass, and $100 \mathrm{~g}$ of PEE/100 g of protein mass. HC was incorporated at concentrations of $0,10,20$, and $30 \mathrm{~g} / 100 \mathrm{~g}$ of protein mass. It was found that increased concentrations of $\mathrm{HC}$ reduced tensile strength and increased elongation; however, all films showed plastic behavior. An increase in solubility at $25^{\circ} \mathrm{C}$, a reduction in the contact angle, and disintegration time were also observed. Thus, higher concentrations of collagen led to more hydrophilic and more soluble polymeric matrices that showed shorter dissolution time, favoring the use of these materials as carriers for active compounds to be delivered in the oral cavity.

Keywords: protein; natural bioactive compounds; disintegration time.
\end{abstract}

\section{Resumo}

Este trabalho teve como objetivo avaliar o efeito de diferentes concentrações de colágeno hidrolisado nas propriedades de filmes de desintegração oral contendo extrato etanólico de própolis como componente ativo. Os filmes foram avaliados em relação aos fenóis totais, propriedade mecânica, solubilidade, ângulo de contato, tempo de desintegração e microestrutura. Os filmes foram produzidos por "casting" com concentrações de $2 \mathrm{~g}$ de massa proteica (gelatina e colágeno hidrolisado), $30 \mathrm{~g}$ de sorbitol/100 g de massa proteica e $100 \mathrm{~g}$ de extrato fenólico de própolis/100 g de massa proteica. Colágeno hidrolisado foi incorporado nas concentrações de $0,10,20$ e $30 \mathrm{~g} / 100 \mathrm{~g}$ de massa proteica. Verificou-se que o aumento da concentração de colágeno hidrolisado provocou redução na tensão de ruptura e aumento da elongação, entretanto todos os filmes apresentaram comportamento plástico. Observou-se também aumento da solubilidade à $25^{\circ} \mathrm{C}$ e redução do ângulo de contato, bem como do tempo de desintegração. Observou-se ainda, que os todos filmes apresentaram concentração considerável de fenóis e estrutura interna porosa. Desta forma, maiores concentrações de colágeno apresentaram matrizes poliméricas mais hidrofílicas, mais solúveis e com menor tempo de dissolução o que favorece a utilização destes materiais como carreadores de componentes ativos para liberação na cavidade oral.

Palavras-chave: proteína; compostos bioativos naturais; tempo de desintegração.

\section{Introduction}

Due to increased concern about health, nowadays there has been growing interest in products enriched or fortified with natural components that have functional properties. Orally disintegrating films may be options for incorporation of these components since they are convenient to use, and there is a large variety of substances that can be used to form the polymer matrix depending on the physicochemical properties of the active component (DIXIT; PUTHLI, 2009; NISHIGAKI et al., 2012). These films are mainly produced using natural macromolecules, such as starch (SHIMODA et al., 2009), proteins (CHEN et al., 2008), blends of chitosan and gelatin (ABRUZZO et al., 2012), microcrystalline cellulose and polyethylene glycol (NISHIGAKI et al., 2012).

Gelatin could be used for the development of orally disintegrating films because of its ability to form a polymer matrix (MANDAL; MANN; KUNDU, 2009; ABRUZZO et al., 2012). Although the capacity of hydrolyzed collagen to form a polymeric matrix has not been proven, it presents other properties, such as assisting bone maintenance because it increases osteoblast activity (GUILLERMINET et al., 2010). Furthermore, hydrolyzed collagen, which is derived from the enzymatic hydrolysis of collagen and not only from acid or alkaline hydrolysis such as gelatin (HOQUE; BENJAKUL; PRODPRAN, 2011), has smaller peptides (OESSER; ADAM; BABEL, 1999), and thus it has higher solubility and possibly affects the characteristics of the film, as well as the process of delivering the active component.

Propolis is mainly composed of organic acids, flavonoids, phenolic compounds, and some enzymes, vitamins, and minerals (BENKOVIC et al., 2007). Among propolis characteristics, antimicrobial, antifungal, antioxidant, anti-inflammatory properties may be emphasized (KOÇ et al., 2011; SILVA et al., 2012) making it a potential source of active components.

Received 3/8/2012

Accepted 25/9/2012 (00T5826)

${ }^{1}$ Department of Food Engineering, Faculty of Animal Science and Food Engineering, University of São Paulo - USP, CEP 13635-900, Pirassununga, SP, Brazil, e-mail: rosecarvalho@usp.br

${ }^{*}$ Corresponding author 
Generally, when in solution, active compounds have the disadvantage of rapidly reducing the concentration in the oral mucosa due to salivation (McNALLY; PARK, 2007). Propolis is widely used as propolis ethanol extract solution. Therefore, the incorporation of PEE in orally disintegrating films may extend the action of the active compounds in the oral cavity.

This study aimed at developing an orally disintegrating film containing propolis ethanol extract as an active component and at evaluating the effect of the incorporation of hydrolyzed collagen into the properties of these films. Films were evaluated in terms of total phenol content, mechanical properties, soluble matter, contact angle, disintegration time, and microstructure.

\section{Materials and methods}

\subsection{Materials}

For the production of orally disintegrating films (ODF), pig skin gelatin (G, 260 Bloom, 40 mesh) and hydrolyzed collagen (HC, B50) were purchased from Gelita Ltda of Brazil (Sao Paulo, Brazil). Sorbitol (Nuclear) was used as plasticizing agent. The preparation of propolis ethanol extract (PEE) was based on type 12 resin (Star Rigel, Raffard - SP) and absolute ethyl alcohol (Labsynth).

\subsection{Preparation of propolis ethanol extract (PEE)}

Propolis resin was ground using a kitchen blender. Propolis ethanol extract (PEE) was produced using $30 \mathrm{~g}$ of resin powder per $100 \mathrm{~mL}$ of alcohol (98\%) (BODINI, 2011). Extraction was carried out under mechanical stirring $(500 \mathrm{rpm})$ at $50{ }^{\circ} \mathrm{C}$ for 30 minutes. Subsequently, the solution was cooled and kept cool for 24 hours and filtered.

\subsection{Production of orally disintegrating films (ODF)}

ODFs were produced by casting, with $2 \mathrm{~g}$ of protein mass (gelatin + HC)/100 g of filmogenic solution; $30 \mathrm{~g}$ of sorbitol/100 g protein mass; and $100 \mathrm{~g}$ of PEE/100 $\mathrm{g}$ of protein mass. Gelatin and hydrolyzed collagen were hydrated at room temperature for 30 minutes, and then solubilized at $50^{\circ} \mathrm{C}$ for 10 minutes. Next, solubilized sorbitol was added to the filmogenic solution, which was maintained at $50{ }^{\circ} \mathrm{C}$ for 10 minutes. PEE was added to the solution and homogenized in an ultra-turrax (IKA, T25-digital Ultra-Turrax, Staufen, German) for 1 minute at $6,000 \mathrm{rpm}$. The film solution was placed in an ultrasound bath (Unique, 1400A, Indaiatuba, Brazil) for 2 minutes and dispersed on the surface of acrylic plates $(12 \times 12 \mathrm{~cm})$. Drying was carried out in a forced circulation oven at $30^{\circ} \mathrm{C}$ for 24 hours. Film thickness was kept constant by controlling the mass/area ratio. Prior to the analyses, the films were placed into desiccators containing saturated solution of $\mathrm{NaBr}$ ( $58 \%$ relative humidity) at room temperature for 5 days. Then, the moisture content of the films was determined gravimetrically. The previously weighed samples were dried in an oven at $105^{\circ} \mathrm{C}$ for 24 hours. Next, they were weighed again and the moisture content was calculated.

\subsection{Determination of total phenol content.}

Total phenol content of the propolis ethanol extract and the orally disintegrating films were determined using the Folin-Ciocateu assay, according to Singleton, Orthofer and
Lamuela-Raventós (1999) with modifications, as follows. PEE was diluted (1:1000) and $0.5 \mathrm{~mL}$ of this solution were added to a tube containing $2.5 \mathrm{~mL}$ of Folin-Ciacauteu reagent (1:10). After 5 minutes, $2.0 \mathrm{~mL}$ of $4 \%$ sodium carbonate were added, and the solution was homogenized. This solution was maintained at rest for 2 hours. Absorbance was measured at $740 \mathrm{~nm}$. For the ODF analysis, the samples (10 to $12 \mathrm{mg}$ of film) were solubilized in $6 \mathrm{~mL}$ of water at $50{ }^{\circ} \mathrm{C}$ (for 50 minutes), subsequently diluted in $4 \mathrm{~mL}$ of ethanol (80\%), and kept at $50{ }^{\circ} \mathrm{C}$ for 10 minutes, which was the solution used to determine total phenol content.

\subsection{Mechanical properties}

The mechanical properties of the films were evaluated by the tensile test using a texturometer TA.XT (Stable Micro Systems, TA.XT.plus, Godalming, England) (THOMAZINE; CARVALHO; SOBRAL, 2005). The samples were cut into strips $(15 \times 100 \mathrm{~mm})$, the grid separation was maintained at $80 \mathrm{~mm}$, and the speed of testing was fixed at $0.9 \mathrm{~mm} \cdot \mathrm{s}^{-1}$. Tensile strength (TS, MPa) and elongation (E, \%) at break are obtained directly from the stress versus elongation curve.

\subsection{Soluble matter (SM)}

The water-soluble matter (SM, \%) was determined according to Gontard et al. (1994). Previously weighed samples of $2.0 \mathrm{~cm}$ in diameter were immersed in $50 \mathrm{~mL}$ of distilled water and kept under mechanical stirring $(63 \mathrm{rpm})$ at $25^{\circ} \mathrm{C}$ for 24 hours. Next, the samples were removed from the solution and dried in an oven (Fanem, oven 515, Sao Paulo, Brazil) at $105^{\circ} \mathrm{C}$ for 24 hours to determine the final mass. The analyses were carried out in triplicate, and the total soluble matter was determined according to Equation 1.

$$
S M=\frac{m i-m f}{m i} 100
$$

where: $\mathrm{SM}=$ percentage of total soluble matter; $\mathrm{mi}=$ initial mass of the sample $(\mathrm{g})$, and $\mathrm{mf}=$ final mass of the sample $(\mathrm{g})$.

\subsection{Contact angle}

Determination of the contact angle was carried out according to Silva et al. (2007) using the optical method in an optical tensiometer (Attension, Theta Lite, Espoo, Finland). The films were cut into rectangles of $20 \times 40 \mathrm{~mm}$. The samples were attached to the base of the equipment, and a drop of deionized water was carefully deposited on the surface of the film using a graduated syringe. The contact angle was obtained by photographs submitted to software analysis after 30 seconds. At least 10 repetitions of the analysis were performed.

\subsection{Disintegration time}

Disintegration time was determined according to Perumal et al. (2008) using film samples of rectangular shape $(2.2 \times 3.5 \mathrm{~cm})$. The samples were immersed in $50 \mathrm{~mL}$ distilled water at $37^{\circ} \mathrm{C}$ under constant stirring at $100 \mathrm{rpm}$. The time for total disintegration (minutes) of the film was determined using a chronometer (Technos, YP2151, Manaus, Brazil). At least 10 repetitions of the analysis were performed. 


\subsection{Scanning electron microscopy}

The film samples were previously placed into desiccators containing silica gel $\left(25^{\circ} \mathrm{C}\right)$ for ten days. For the surface analysis, the sample was attached to the conductive copper tape, and for the internal structure analysis, the cryofracture technique was used. Next, the samples were analyzed by scanning electron microscopy (Hitachi Ltd, TM-3000, Tokyo, Japan) of images of the surface and internal structure (fracture). The samples were evaluated at $1,000 \times$ magnification for the surface images and at 3,000× magnification for fractures with an acceleration voltage of $15 \mathrm{kV}$.

\subsection{Statistical analysis}

Statistical analyses were carried out using SAS software (Version 9.2, SAS, Inc.). The difference between means was determined by Duncan's test (95\% confidence interval).

\section{Results and discussion}

\subsection{Total phenol content}

PEE showed a concentration of $35.18 \mathrm{mg}$ of gallic acid/g of PEE. This result is similar to that reported by Mohammadzadeh et al. (2007). For all films analyzed, no significant differences were observed in total phenol content, and means of $27.6 \mathrm{mg}$ of gallic acid/g of film were observed. Therefore, it could be noted that, after the processing and drying of the films, regardless of the formulation, phenolic compounds were not degraded.

Similar results were observed by Bodini (2011), who evaluated gelatin films with twice the PEE concentration used in the present study and observed concentrations of $51.5 \mathrm{mg}$ of gallic acid/g of film.

\subsection{Mechanical properties}

The stress versus strain curves of the films shown in Figure 1 represent the mechanical behavior of films with different concentration of hydrolyzed collagen, and all films showed a behavior similar to plastic material (CALISTER JUNIOR, 2008). In the samples studied, it was found (Table 1) that the increase in the concentration of hydrolyzed collagen did not affect the moisture content of the films after conditioning even though collagen is more hydrophilic than gelatin. On the other hand, the increase in the concentration of hydrolyzed collagen caused a reduction in the tensile strength and an increase in elongation (Figure 1 and Table 1). It is possible that due to the low molecular weight of hydrolyzed collagen, its incorporation decreased the cohesiveness of the polymer matrix, resulting in reduced resistance and increased flexibility.

The mechanical properties strongly depend on the formulation used, and in the case of orally disintegrating films, this formulation should ensure the integrity of the matrix to protect the active compounds and that the material is easy to handle. Different values for the mechanical properties of orally disintegrating films were found in the literature. Dong, Wang and Du (2006) studied alginate/gelatin film cross-linked with $\mathrm{Ca}^{2+}$ and verified that films with $100 \%$ of gelatin and plasticized

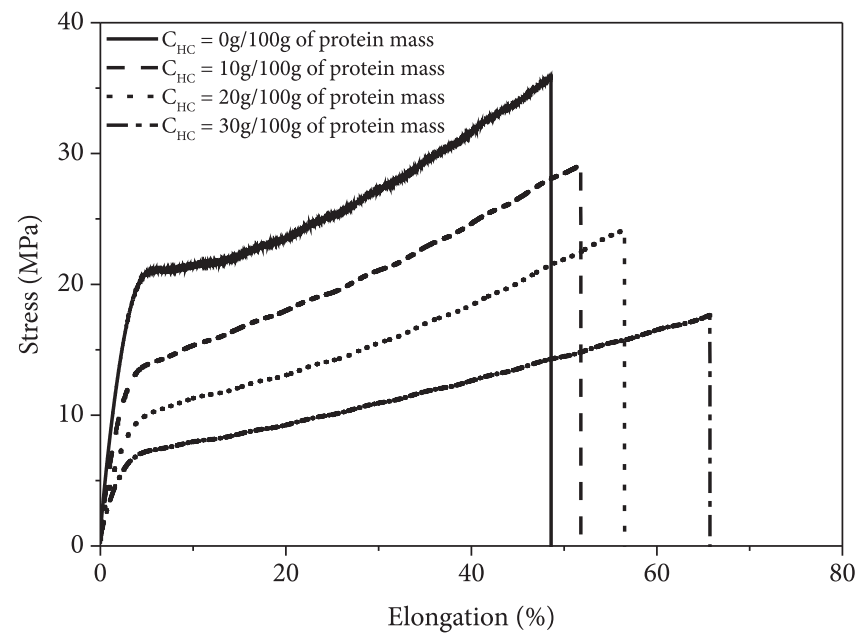

Figure 1. Effect of the hydrolyzed collagen concentration $\left(\mathrm{C}_{\mathrm{HC}}\right)$ on the mechanical properties of orally disintegrating films with propolis ethanol extract.

Table 1. Effect of hydrolyzed collagen concentration $\left(\mathrm{C}_{\mathrm{HC}}\right)$ on moisture content (MC), tensile strength (TS), and elongation (E).

\begin{tabular}{cccc}
\hline $\mathrm{C}_{\mathrm{HC}}(\mathrm{g} / 100 \mathrm{~g}$ de MP $)$ & $\mathrm{MC}(\%)$ & $\mathrm{TS}(\mathrm{MPa})$ & $\mathrm{E}(\%)$ \\
\hline 0 & $12.1 \pm 0.7^{\mathrm{a}}$ & $31.3 \pm 2.9^{\mathrm{a}}$ & $48.2 \pm 4.3^{\mathrm{c}}$ \\
10 & $11.9 \pm 0.7^{\mathrm{a}}$ & $27.2 \pm 2.6^{\mathrm{b}}$ & $52.6 \pm 3.9^{\mathrm{b}, \mathrm{c}}$ \\
20 & $12.5 \pm 0.7^{\mathrm{a}}$ & $23.8 \pm 2.2^{\mathrm{c}}$ & $56.5 \pm 5.2^{\mathrm{b}}$ \\
30 & $13.1 \pm 0.8^{\mathrm{a}}$ & $18.0 \pm 1.7^{\mathrm{d}}$ & $65.2 \pm 6.2^{\mathrm{a}}$ \\
\hline
\end{tabular}

a,b,c,d Different letters in the same column indicate significant differences between the means obtained according to the Duncan's test $(\mathrm{p}<0.05)$.

with glycerol showed similar tensile strength (about $40 \mathrm{MPa}$ ), but they had smaller breaking elongation (about 4.5\%), than that of the films of the present study. Chen et al. (2008) found values between 0.7 to $1.7 \mathrm{MPa}$ for tensile strength and 52.0 to $173.1 \%$ for breaking elongation of soy protein film. Mandal, Mann and Kundu (2009) studied silk fibroin/gelatin film and found greater values of tensile strength (about $110 \mathrm{MPa}$ ) and shorter elongation (about 9.5\%).

\subsection{Soluble matter}

Figure 2 shows that the increase in the concentration of hydrolyzed collagen significantly increased the percentage of total soluble matter of the orally disintegrating film in water at $25^{\circ} \mathrm{C}$, as a function of the low molecular weight of the hydrolyzed collagen and its higher hydrophilicity in relation to gelatin.

Considering the components delivery, higher solubility is a desirable feature. Thus, the addition of collagen increases the solubility of the matrix enabling faster delivery of the active component in the site of interest. Water solubility observed in this study was similar to that reported in the literature for gelatin films. Alves et al. (2011) evaluated the solubility of gelatin films and polyvinyl alcohol and found values between 46.2 and $47.7 \%$, and Bodini (2011) studied the use of gelatin films with PEE and found values of about $31.1 \%$. 


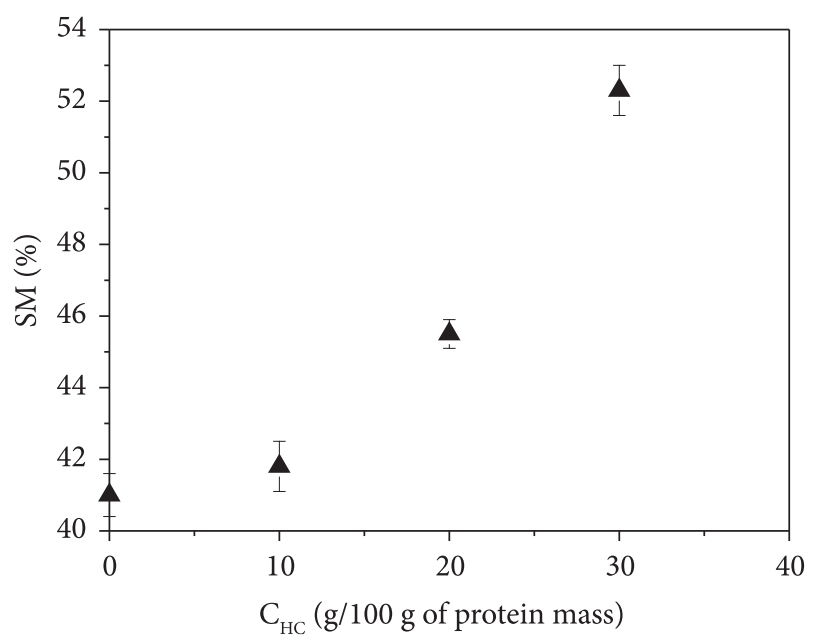

Figure 2. Effect of the concentration of hydrolyzed collagen $\left(\mathrm{C}_{\mathrm{HC}}\right)$ on the total soluble matter (SM) of orally disintegrating films with propolis ethanol extract.

\subsection{Contact angle}

The results of the contact angles of the films are shown in Table 2. A significant decrease in the contact angle was observed only for the film with higher concentration of hydrolyzed collagen (30 g/100 g of protein mass) indicating greater wettability in relation to the other films (FLORENCE; ATTWOOD, 2003). This decrease may be related to the increased hydrophilicity of the films due to the high concentration of hydrolyzed collagen. An increase in wettability is interesting because when placed in the oral cavity, the orally disintegrating films should exhibit instant wettability for delivery of the active components.

The values found in this study were higher than those of other films reported in the literature. Otto et al. (2008) found values of contact angle of about $80^{\circ}$ for films based on poly(styrene-co-methyl methacrylate) and poly(syrene-co-ethyl methacrylate). Lue et al. (2011) studied N-isopropylacrylamide films and evaluated the effect of incorporation of particles of acrylic acid (which is more hydrophilic than the matrix macromolecules) into the contact angle, and they observed that it was reduced $\left(71.3\right.$ to $\left.63.7^{\circ}\right)$ when the concentration of these particles increased. There were no studies on the contact angle for protein-based orally disintegrating films.

\subsection{Disintegration time}

As shown in Figure 3, the increase in the hydrolyzed collagen reduced the disintegration time. This result corroborates the values found for total soluble matter, which showed that the concentration of hydrolyzed collagen increased as well. The results were related to the higher hydrophilicity and the reduced molecular weight of hydrolyzed collagen.

Films based on polysaccharides, for example, show much shorter disintegration times than those of protein-based films. Shimoda et al. (2009) studied films based on microcrystalline cellulose, polyethylene glycol, hydroxypropylmethyl cellulose, and hydroxypropyl cellulose containing dexamethasone and
Table 2. Effect of hydrolyzed collagen concentration $\left(\mathrm{C}_{\mathrm{HC}}\right)$ on contact angle (CA).

\begin{tabular}{cc}
\hline $\mathrm{C}_{\mathrm{HC}}(\mathrm{g} / 100 \mathrm{~g}$ de MP $)$ & $\mathrm{CA}\left(^{\circ}\right)$ \\
\hline 0 & $88.3 \pm 2.0^{\mathrm{a}}$ \\
10 & $87.5 \pm 4.7^{\mathrm{a}}$ \\
20 & $86.1 \pm 3.4^{\mathrm{a}, \mathrm{b}}$ \\
30 & $84.0 \pm 5.4^{\mathrm{b}}$ \\
\hline
\end{tabular}

a,b Different letters in the same column indicate significant differences between the means according to the Duncan's test $(\mathrm{p}<0.05)$.

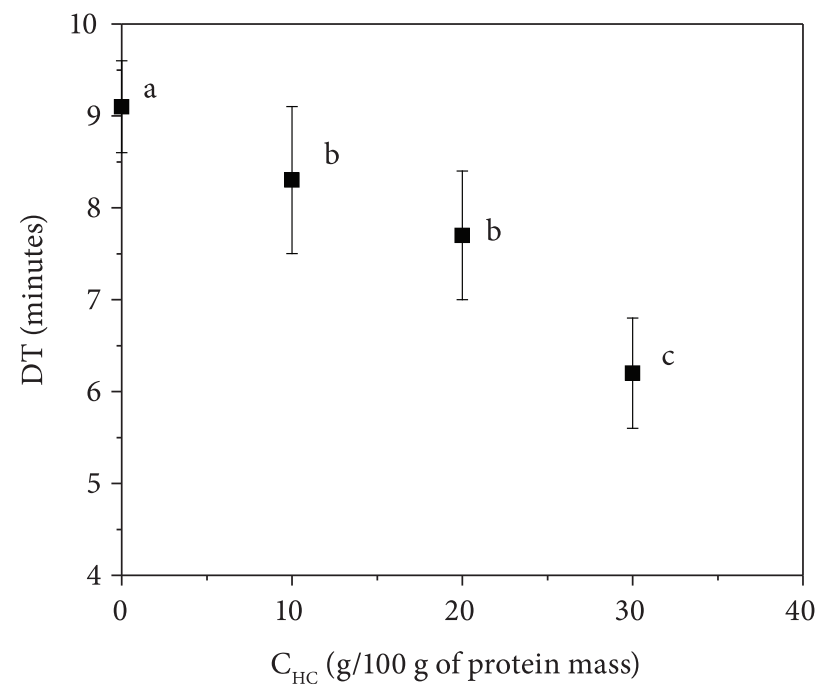

Figure 3. Effect of the concentration of hydrolyzed collagen $\left(\mathrm{C}_{\mathrm{HC}}\right)$ on the disintegration time (DT) of orally disintegrating film with propolis ethanolic extract.

found a disintegration time of 12.5 seconds in water. Liew, Tan and Peh (2012) reported a time of 43 seconds for orally disintegrating films based on hydroxypropyl methylcellulose, corn starch, polyethylene glycol, and films with lactose monohydrate with donepezil. Moreover, Abruzzo et al. (2012) studied chitosan/gelatin films and, for the films that were made only with gelatin, they observed complete disintegration in an average of 10 minutes at $\mathrm{pH} 6.8$.

\subsection{Scanning electron microscopy}

In the surface analysis, all films showed cohesive and homogeneous matrix. The internal structure (Figure 4) of the films incorporated with propolis ethanol extract showed the presence of pores in the polymer matrix, regardless of the concentration of hydrolyzed collagen added, possibly due to the process used for propolis ethanol extract incorporation.

Similar results were reported by Bodini (2011), who evaluated gelatin films incorporated with PEE and found the formation of cohesive and homogeneous matrix in the analysis of film surface. The analysis of the internal structure also showed that increasing the concentration of propolis increased the porosity of the polymer matrix, and it indicated good dispersion of the components in the matrix. 

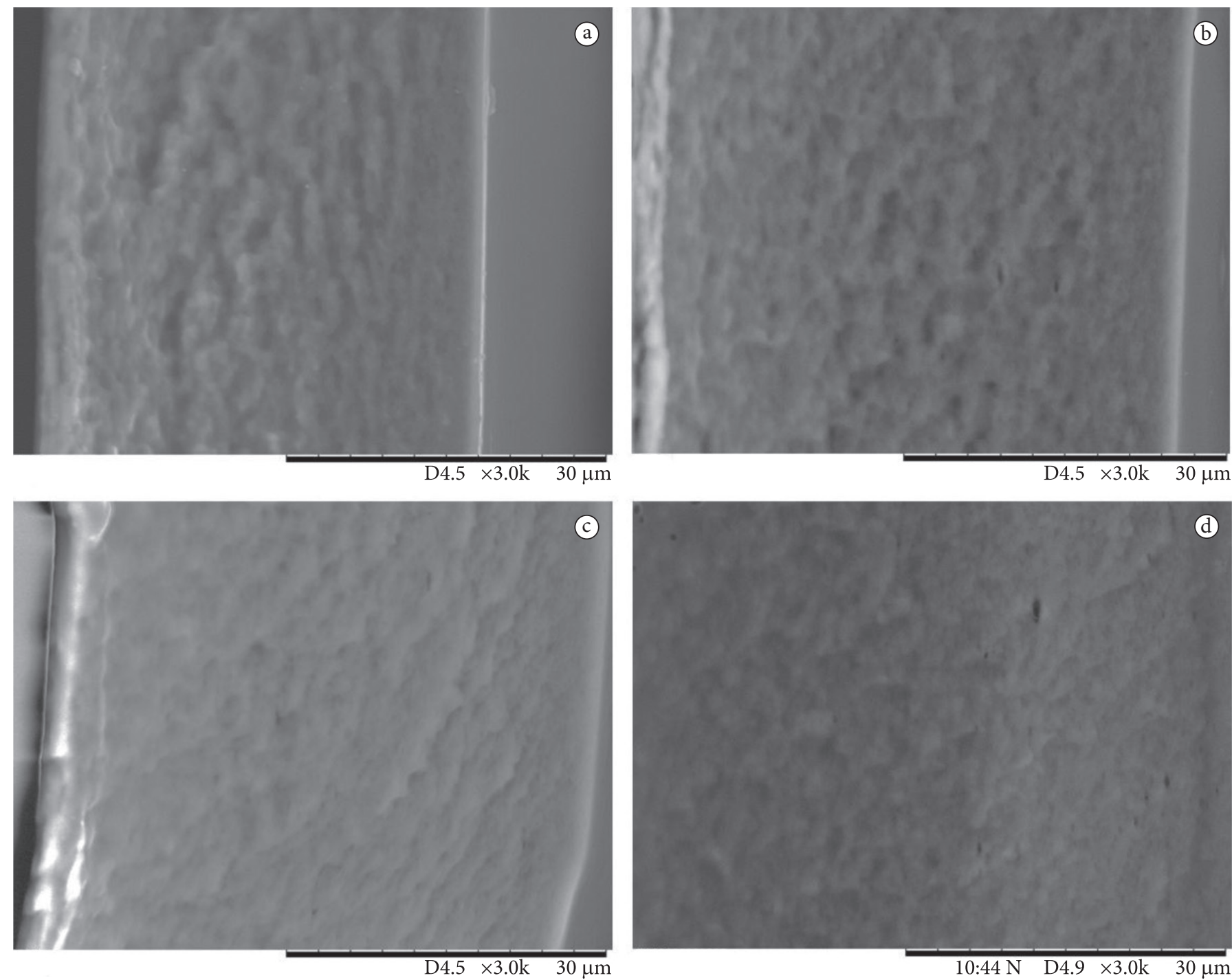

Figure 4. Micrographs of the internal structure after cryofracture of the films: a) $\mathrm{C}_{\mathrm{HC}}=0 \mathrm{~g} / 100 \mathrm{~g}$ of protein mass; $\left.\mathrm{b}\right) \mathrm{C}_{\mathrm{HC}}=10 \mathrm{~g} / 100 \mathrm{~g}$ of protein mass; c) $\mathrm{C}_{\mathrm{HC}}=20 \mathrm{~g} / 100 \mathrm{~g}$ of protein mass, and d) $\mathrm{C}_{\mathrm{HC}}=30 \mathrm{~g} / 100 \mathrm{~g}$ of protein mass (magnification of $3,000 \times$ ).

\section{Conclusions}

Orally disintegrating films based on gelatin and hydrolyzed collagen may be good alternatives to be used as vehicles for active components from propolis ethanol extract. As shown in the mechanical property analysis, these films were not brittle and proved to be easy to handle. Hydrolyzed collagen has low molecular weight, which makes it more soluble than gelatin. Therefore, an increase in its concentration increased solubility and reduced disintegration times and contact angles, with consequent increased film wettability. Moreover, the films analyzed exhibited high total phenol content, which indicates that the processing did not degrade the active compounds of interest. Thus, hydrolyzed collagen can be used as an alternative to control the delivery of the active components, and consequently, the time of action of these components.

\section{Acknowledgements}

The authors gratefully acknowledge CAPES for the research scholarship granted to the first author and FAPESP for the financial support.

\section{References}

ABRUZZO, A. et al. Mucoadhesive chitosan/gelatin films for buccal delivery of propranolol hydrochloride. Carbohydrate polymers, v. 87, n. 1, p. 581-588, 2012. http://dx.doi.org/10.1016/j. carbpol.2011.08.024

ALVES, P. M. A. et al. Development of films based on blends of gelatin and poly(vinyl alcohol) cross linked with glutaraldehyde. Food Hydrocolloids, v. 25, n.7, p. 1751-1757, 2011. http://dx.doi. org/10.1016/j.foodhyd.2011.03.018

BENKOVIC, V. et al. Enhanced antitumor activity of irinotecan combined with propolis and its polyphenolic compounds on Ehrlich 
ascites tumor in mice. Biomedicine \& Pharmacotherapy, v. 61, n. 5, p. 292-297, 2007. PMid:17412551. http://dx.doi.org/10.1016/j. biopha.2007.02.012

BODINI, R. B. Desenvolvimento de materiais poliméricos bioativos à base de gelatina e própolis. 2011. $86 \mathrm{f}$. Dissertação (Mestrado em Ciências da Engenharia de Alimentos)-Faculdade de Zootecnia e Engenharia de Alimentos, Universidade de São Paulo, Pirassununga, 2011. PMCid:3002838.

CALISTER JUNIOR, W. D. Ciência e engenharia de materiais: uma introdução. 7. ed. Rio de Janeiro: LTC, 2008. 705 p.

CHEN, L. et al. Kinetics of the breakdown of cross-linked soy protein films for drug delivery. Biomaterials, v. 29, n. 27, p. 3750-3756, 2008. PMid:18547639. http://dx.doi.org/10.1016/j. biomaterials.2008.05.025

DIXIT, R. P.; PUTHLI, S. P. Oral strip technology: overview and future potential. Journal of Controlled Release, v. 139, n. 2, p. 94-107, 2009. PMid:19559740. http://dx.doi.org/10.1016/j. jconrel.2009.06.014

DONG, Z.; WANG, Q.; DU, Y. Alginate/gelatin blend films and their properties for drug controlled release. Journal of Membrane Science, v. 280, n. 1-2, p. 37-44, 2006. http://dx.doi.org/10.1016/j. memsci.2006.01.002

FLORENCE, A. T.; ATTWOOD, D. Princípios físico-químicos em farmácia. 3. ed. São Paulo: EDUSP, 2003. 732 p. PMCid:1738397.

GONTARD, N. et al. Edible composite films of wheat gluten and lipids: water vapour permeability and other physical properties. International Journal of Food Science and Technology, v. 1994, p. 39-50, 1994

GUILLERMINET, F. et al. Hydrolyzed collagen improves bone metabolism and biomechanical parameters in ovariectomized mice: an in vitro and in vivo study. Bone, v. 46, n. 3, p. 827-34, 2010. Pmid:19895915. http://dx.doi.org/10.1016/j.bone.2009.10.035

HOQUE, M. S.; BENJAKUL, S.; PRODPRAN, T. Effects of partial hydrolysis and plasticizer content on the properties of film from cuttlefish (Sepia pharaonis) skin gelatin. Food Hydrocolloids, v. 25, n. 1, p. 82-90,2011. http://dx.doi.org/10.1016/j.foodhyd.2010.05.008

KOÇ, A. et al. Antifungal Activity of the Honeybee Products Against Candida spp. and Trichosporon spp. Journal of Medicinal Food, v. 14 , n. 1-2, p. 128-134, 2011. PMid:21128826. http://dx.doi. org/10.1089/jmf.2009.0296

LIEW, K. B.; TAN, Y. T. F.; PEH, K. K. Characterization of oral disintegrating film containing donepezil for Alzheimer disease. AAPS PharmSciTech, v. 13, n. 1, p. 134-142, 2012. PMid:22167416. http://dx.doi.org/10.1208/s12249-011-9729-4

LUE, S. J. et al. Grafting of poly(N-isopropylacrylamide-co-acrylic acid) on micro-porous polycarbonate films: Regulating lower critical solution temperatures for drug controlled release. Journal of Membrane Science, v. 379, n. 1-2, p. 330-340, 2011. http://dx.doi. org/10.1016/j.memsci.2011.06.002

MANDAL, B. B.; MANN, J. K.; KUNDU, S. C. Silk fibroin/gelatin multilayered films as a model system for controlled drug release.
European Journal of Pharmaceutical Sciences, v. 37, n. 2, p. 160-171, 2009. http://dx.doi.org/10.1016/j.ejps.2009.02.005. PMid:19429423

McNALLY, E. J.; PARK, J. Y. Peptides and Proteins: Oral Absorption. In: SWARBRICK, J. (Ed.). Encyclopedia of Pharmaceutical Technology. 3rd ed. New York: Informa Healthcare USA, 2007. v. 4, p. 2713-2730.

MOHAMMADZADEH, S. et al. Antioxidant power of Iranian propolis extract. Food Chemistry, v. 103, p. 729-733, 2007. http://dx.doi. org/10.1016/j.foodchem.2006.09.014

NISHIGAKI, M. et al. Development of fast dissolving oral film containing dexamethasone as an antiemetic medication: Clinical usefulness. International Journal of Pharmaceutics, v. 424, n. 1-2, p. 12-17, 2012. PMid:22240389. http://dx.doi.org/10.1016/j. ijpharm.2011.12.057

OESSER, S.; ADAM, M.; BABEL, W. Oral Administration of 14 C Labeled Gelatin Hydrolysate Leads to an Accumulation of Radioactivity in Cartilage of Mice (C57/BL). Journal of Nutrition, v. 129, n. 10, p. 1891-1895, 1999. PMid:10498764.

OTTO, D. P. et al. Development of microporous drug-releasing films cast from artificial nanosized latexes of poly](styrene-co-methyl methacrylate) or poly(styrene-co-ethyl methacrylate. European Journal of Pharmaceutics and Biopharmaceutics, v. 69 , n. 3, p. 1121-1134, 2008. PMid:18417330. http://dx.doi.org/10.1016/j. ejpb.2008.02.004

PERUMAL, V. A. et al. Formulation of monolayered films with drug and polymers of opposing solubilities. International Journal of Pharmaceutics, v. 358, n. 1-2, p. 184-191, 2008. PMid:18430529. http://dx.doi.org/10.1016/j.ijpharm.2008.03.005

SHIMODA, H. et al. Preparation of a fast dissolving oral thin film containing dexamethasone: a possible application to antiemesis during cancer chemotherapy. European Journal of Pharmaceutics and Biopharmaceutics, v. 73, n. 3, p. 361-5, 2009. PMid:19735731. http://dx.doi.org/10.1016/j.ejpb.2009.08.010

SILVA, J. C. et al. Antimicrobial activity, phenolic profile and role in the inflammation of propolis. Food and Chemical Toxicology, v. 50, p. 1790-1795, 2012. PMid:22425940. http://dx.doi.org/10.1016/j. fct.2012.02.097

SILVA, W. A. et al. Determinação da cor, imagem superficial topográfica e ângulo de contato de biofilmes de diferentes fontes de amido. Ciência e Agrotecnologia, v. 31, p. 154-163, 2007. http://dx.doi. org/10.1590/S1413-70542007000100023

SINGLETON, V. L.; ORTHOFER, R.; LAMUELA-RAVENTÓS, R. Analysis of total phenols and other oxidation substrates and antioxidants by means of Folin-Ciocalteu reagent. Methods in Enzymology, v. 299, p. 152-178, 1999. http://dx.doi.org/10.1016/ S0076-6879(99)99017-1

THOMAZINE, M.; CARVAlHO, R. A.; SOBRAL, P. J. A. Physical properties of gelatin films plasticized by blends of glycerol and sorbitol. Journal of Food Science, v. 70, n. 2, p. 172-176, 2005. 